Northwestern University School of Law

Northwestern University School of Law Scholarly Commons

Faculty Working Papers

2010

\title{
Forced Labor, Revisited: The Thirteenth Amendment and Abortion
}

Andrew Koppelman

Northwestern University School of Law, akoppelman@law.northwestern.edu

\section{Repository Citation}

Koppelman, Andrew, "Forced Labor, Revisited: The Thirteenth Amendment and Abortion" (2010). Faculty Working Papers. Paper 32. http://scholarlycommons.law.northwestern.edu/facultyworkingpapers/32 
Forthcoming in Alexander Tsesis, ed., Promises of Liberty: Thirteenth Amendment Abolitionism and Its Contemporary Vitality, Columbia University Press, 2010.

\title{
Forced Labor, Revisited: The Thirteenth Amendment and Abortion
}

\author{
Andrew Koppelman
}

The longer I live the more I see that I am never wrong about anything, and that all the pains I have so humbly taken to verify my notions have only wasted my time.

\section{Bernard Shaw ${ }^{1}$}

Dawn Johnsen, as this is written the nominee to head the Office of Legal Counsel, ${ }^{2}$ wrote an amicus brief which argued in passing that restrictions on abortion "are disturbingly suggestive of involuntary servitude, prohibited by the Thirteenth Amendment, in that forced pregnancy requires a woman to provide continuous physical service to the fetus in order to further the state's asserted interest. Indeed, the actual process of delivery demands work of the most intense and physical kind: labor of 12 or more grueling hours of contractions is not uncommon." After she was nominated as OLC head, Senator Arlen Specter declared that this passage raised "real questions in my mind about her competency to handle this important job." The argument is, "to say startling would be a mild characterization," said Specter. "It seems to me pretty hard to say that that's an arguable legal position."

Senator Specter misunderstood Johnsen's position. To say that one thing is "disturbingly suggestive" of another is hardly the same as saying that it is identical to that other thing. Johnsen made this point to support her Fourteenth Amendment claim, by showing the serious nature of the liberty interest that is at stake. The brief does not argue that the state laws violate the Thirteenth Amendment. She quickly made clear in subsequent statements that she had made no Thirteenth Amendment argument.

If there was any point of consensus that came out of this sorry episode, it was that if you want to be taken seriously, you had better not make a Thirteenth Amendment

\footnotetext{
${ }^{1}$ Bernard Shaw, letter to H.G. Wells, 7 December 1916, in Collected Letters, 1911-1925, at 439 (Dan H. Laurence ed. 1985).

${ }^{2}$ As this is written, in November 2009, Johnsen's confirmation remains in doubt, and Senator Specter, who recently became a Democrat, remains opposed to her nomination.

${ }^{3}$ Specter Remarks on Qualifications of Nominee to Head DOJ Office of Legal Counsel, Congressional Documents and Publications, Mar. 19, 2009. Senator Specter also, very unfortunately, cited me as authority for the position that Johnsen had made a Thirteenth Amendment argument. This was based on a misreading both of my article and Johnsen's brief. See Andrew Koppelman, Lying About Dawn Johnsen, available at http://balkin.blogspot.com/2009/04/lying-about-dawn-johnsen.html (visited April 3, 2009).
} 
argument on behalf of abortion. That is beyond the pale. Senator Specter and his supporters ${ }^{4}$ also made it clear that they regarded the position as so clearly wrong that it was not necessary to even give a hint as to what was wrong with it. In this they continued a long tradition of casual dismissal. It is not even clear that they understand the argument.

Most of the articles in this book, I am sure, break new ground, deploying the Thirteenth Amendment in new and creative ways. This is not one of them. I am going to restate an argument I made long ago, in my first article (not counting my law journal Note), written in law school and published while I was still a graduate student. ${ }^{5}$ I'm going to then consider how the work was received, offer some amendments to the argument, and conclude with some reflections on how, perhaps, it can have more influence in the future.

I. The basic argument

The Thirteenth Amendment reads as follows:

1. Neither slavery nor involuntary servitude, except as a punishment for crime whereof the party shall have been duly convicted, shall exist within the United States, or any place subject to their jurisdiction.

2. Congress shall have the power to enforce this article by appropriate legislation.

My claim is that the amendment is violated by laws that prohibit abortion. When women are compelled to carry and bear children, they are subjected to "involuntary servitude" in violation of the amendment. Abortion prohibitions violate the Amendment's guarantee of personal liberty, because forced pregnancy and childbirth, by compelling the woman to serve the fetus, creates "that control by which the personal service of one man [sic] is disposed of or coerced for another's benefit which is the essence of involuntary servitude." ${ }^{6}$ Such laws violate the amendment's guarantee of equality, because forcing women to be mothers makes them into a servant caste, a group which, by virtue of a status of birth, is held subject to a special duty to serve others and not themselves.

This argument makes available two responses to the standard defense of such prohibitions, the claim that the fetus is a person. The first is that even if this is so, its right to the continued aid of the woman does not follow. As Judith Jarvis Thomson observes, "having a right to life does not guarantee having either a right to be given the use of or a right to be allowed continued use of another person's body -- even if one needs

\footnotetext{
${ }^{4}$ The most prominent of these was the National Review Online columnist Andrew McCarthy, who calls the argument "lunatic" and "farcical," but whose analysis does not proceed beyond the exuberant application of adjectives. See Andrew McCarthy, “Lawyer's Lawyer, Radical's Radical,” National Review Online, March 9, 2009.

5 Andrew Koppelman, Forced Labor: A Thirteenth Amendment Defense of Abortion, 84 Nw. U. L. Rev. 480 (1990).

${ }^{6}$ Bailey v. Alabama, 219 U.S. 219, 241 (1911).
} 
it for life itself." ${ }^{7}$ Giving fetuses a legal right to the continued use of their mothers' bodies would be precisely what the Thirteenth Amendment forbids. The second response is that since abortion prohibitions infringe on the fundamental right to be free of involuntary servitude, the burden is on the state to show that the violation of this right is justified. Since the thesis that the fetus is, or should at least be considered, a person seems impossible to prove (or to refute), this is a burden that the state cannot carry. If we are not certain that the fetus is a person, then the mere possibility that it might be is not enough to justify violating women's Thirteenth Amendment rights by forcing them to be mothers.

This is not a purely textual argument. It builds heavily on the Thirteenth Amendment caselaw - caselaw that is likely to be unfamiliar to many readers. The unfamiliarity presents a difficulty that I did not see when I wrote the original article. At that time, I naively believed what I had been taught in law school: that, if caselaw has been laid down by the Supreme Court, repeatedly followed, and never overruled, then it can be relied on as a source of law. The reality isn't that simple. But first, let me describe the argument.

Most of the jurisprudence surrounding the amendment concerns Congress' power under the second section, ${ }^{8}$ but I want to begin by focusing on the first, which is selfexecuting. ${ }^{9}$ Although primarily directed against the slavery of the antebellum South, the amendment is broader in scope, as the Court held when it first considered the amendment in the Slaughter House Cases.

Undoubtedly while negro slavery alone was in the mind of the Congress which proposed the thirteenth article, it forbids any other kind of slavery, now or hereafter. If Mexican peonage or the Chinese coolie labor system shall develop slavery of the Mexican or Chinese race within our territory, this amendment may safely be trusted to make it void. ${ }^{10}$

\footnotetext{
${ }^{7}$ Judith Jarvis Thomson, A Defense of Abortion, 1 Phil. \& Pub. Aff. 47, 56 (1971).

${ }^{8}$ The major cases are United States v. Harris, 106 U.S. 629 (1883) (invalidating conspiracy section of 1871 Ku Klux Klan Act); the Civil Rights Cases, 109 U.S. 3 (1883) (invalidating 1875 Civil Rights Act's ban on racial discrimination in public accommodations); Clyatt v. United States, 197 U.S. 207 (1905) (sustaining anti-peonage statute); Hodges v. United States, 203 U.S. 1 (1906) (invalidating law against conspiracies to deprive blacks of their rights); and Jones v. Alfred H. Mayer Co., 392 U.S. 409 (1968) (overruling Hodges, and holding that Congress has broad power to identify and eliminate "badges of slavery"). Two useful general histories of Thirteenth Amendment jurisprudence are G. Sidney Buchanan, The Quest for Freedom: A Legal History of the Thirteenth Amendment (1976), and Howard D. Hamilton, The Legislative \& Judicial History of the Thirteenth Amendment, 9 Nat'1 B.J. 26 (1951).

${ }^{9}$ The Court's late 20th century decisions have included dicta to the effect that the Court has not yet decided whether the self-executing provision did more than free the slaves. See City of Memphis v. Greene, 451 U.S. 100, 125-6 (1981); Jones v. Alfred H. Mayer Co., 392 U.S. 409, 439 (1968); General Building Contractors Assn. v. Pennsylvania, 458 U.S. 375, 390 n.17 (1982). This is not accurate. In its early twentieth century cases invalidating laws that effectively imposed peonage, the Court consistently held those laws to be in conflict with both the Thirteenth Amendment and the federal statutes authorized by it. Bailey v. Alabama, 219 U.S. 219, 239, 245 (1911): United States v. Reynolds, 235 U.S. 133, 150 (1914); Taylor v. Georgia, 315 U.S. 25, 31 (1942); Pollock v. Williams, 322 U.S. 4, 25 (1944).

${ }^{10}$ Slaughter House Cases, 83 U.S. (16 Wall.) 36, 72 (1873).
} 
The Court also said that "the word servitude is of larger meaning than slavery, as the latter is popularly understood in this country .... It was very well understood that ... the purpose of the article might have been evaded, if only the word slavery had been used."11

What then, does the amendment protect? I said at the outset that the amendment is concerned with both liberty and equality. Each of these concerns is reflected in a different body of case law. Consider them in turn.

\section{A. Liberty}

The Court has explained that "involuntary servitude" refers to "the control of the labor and services of one man for the benefit of another, and the absence of a legal right to the disposal of his own person, property and services;" compulsory service of one to another," 13 "that control by which the personal service of one man is disposed of or coerced for another's benefit which is the essence of involuntary servitude. ${ }^{14}$

Thus defined, it follows that "involuntary servitude" includes coerced pregnancy. The pregnant woman may not serve at the fetus' command -- it is the state that, by outlawing abortion, supplies the element of $\operatorname{coercion}^{15}$-- but she is serving involuntarily for the fetus' benefit, and this is what the Court has said that the amendment forbids. If citizens may not be forced to surrender control of their persons and services, then women's persons may not be invaded and their services may not be coerced for the benefit of fetuses. It is as simple as that. The injury inflicted on women by forced motherhood is lesser in degree than that inflicted on blacks by antebellum slavery, since it is temporary and involves less than total control over the body, but it is the same kind of injury. When abortion is outlawed, the pregnant woman must serve the fetus, and that servitude is involuntary.

Some of those to whom I've made this argument have responded less with skepticism than with horror. They take it to be a libel on motherhood, which far from being like slavery is an exhilarating, awe-inspiring and joyous experience. ${ }^{16}$ It may not be out of place, therefore, to address this concern at the outset. The objection gathers whatever force it has by focusing on the experience of women who want to be mothers. But the Thirteenth Amendment doesn't apply to them. The servitude it is concerned with

\footnotetext{
${ }^{11} \underline{\mathrm{Id}}$.

${ }^{12}$ Plessy v. Ferguson, 163 U.S. 537, 542 (1896) (emphases added).

${ }^{13}$ Hodges v. United States, 203 U.S. 1, 16 (1906).

${ }^{14}$ Bailey v. Alabama, 219 U.S. 219, 241 (1911).

${ }^{15}$ The same is, of course, true of any system of slavery sanctioned by positive law, such as that of the antebellum South: the master did not need to resort to self-help to control his slaves, but could rely on the authorities to come to his assistance if necessary.

${ }^{16}$ The argument is denounced as "bizarre" on this basis in Wendy Wright, U.N. Meeting on Women Ends in Chaos, Mar. 20, 2003, Concerned Women for America website, http://www.cwfa.org/articles/3596/CWA/nation/index.htm (visited May 31, 2007).
} 
is involuntary. The distinction between wanted and unwanted pregnancy is like the difference between wanted and unwanted sex. Can rape be defended on the grounds that sex is an exhilarating, awe-inspiring, joyous experience? Are arguments that focus on the degrading and violative aspects of rape a libel on sex? Plantation slavery cannot be justified on the grounds that many people find gardening deeply satisfying.

Women differ from men in that the services they are capable of performing include the production of human beings. The Thirteenth Amendment, however, draws no distinction between the powers of a man's back and arms and those of a woman's uterus. Both, according to the amendment, belong to the individual who possesses them and cannot be made subject to the command or benefit of another. Indeed, the recent advent of "surrogate motherhood" has shown that women's reproductive powers are as capable as any other of being transacted for in the marketplace, a marketplace that the Thirteenth Amendment establishes as "a system of completely free and voluntary labor throughout the United States." 17

The compulsion of women to use those reproductive powers for purposes not their own is incompatible with the amendment's strong declaration of universal personal liberty. As the second Justice Harlan observed, the acts of the Reconstruction Congress reflected "the individualistic ethic of their time, which emphasized personal freedom and embodied a distaste for governmental interference which was soon to culminate in the era of laissez-faire. . . . [M] ost of these men would have regarded it as a great intrusion on individual liberty for the Government to take from a man [sic] the power to refuse for personal reasons to enter into a purely private transaction ...." ${ }^{18}$ Doubtless these men's vision of liberty did not extend to women's control over their childbearing capacities. ${ }^{19}$ But the framers did enact that vision in broad language whose scope did not exclude women, ${ }^{20}$ and there is no principled reason for excluding women from it today. ${ }^{21}$

\footnotetext{
${ }^{17}$ Pollock v. Williams, 322 U.S. 4, 17 (1944); cf. Bailey, 219 U.S. at 245.

18 Jones v. Alfred H. Mayer Co., 392 U.S. 409, 473-74 (1968) (Harlan, J., dissenting).

${ }^{19}$ Opponents of the amendment did, however, express fears about its radical egalitarianism which went unanswered by its proponents. See, e.g., Cong. Globe, 38th Cong., 1st Sess. 1488 (1864) (remarks of Sen. Howard) ("I suppose before the law a woman would be equal to a man, would be as free as a man. A wife would be equal to her husband and as free as her husband before the law."); Cong. Globe, 38th Cong., 2nd Sess. 215 (1865) (remarks of Rep. White) ("A husband has a right of property in the service of his wife; he has the right to the management of his household affairs. . . All of these rights rest upon the same basis as a man's right of property in the service of slaves.").

${ }^{20}$ Unlike, for example, the suffrage provisions of the Fourteenth Amendment. See U.S. Const., Amend. XIV, Sec. 2 (reducing Congressional representation of a state if "the right to vote . . . is denied to any of the male inhabitants of such State").

${ }^{21}$ Whatever reasons justify the extension of Fourteenth Amendment rights to women apply, mutatis mutandis, to the Thirteenth Amendment as well. That the Thirteenth Amendment is not confined to injuries to blacks, or even to those based on race, was suggested by the Court in Griffin v. Breckenridge, 403 U.S. 88 (1971), which held that the Ku Klux Klan act, outlawing private conspiracies to deprive any class of persons of their constitutional rights, was a valid exercise of Congress' Thirteenth Amendment powers. In order to avoid creating a general federal tort law, the Court held that the mental element required for a violation of the statute was "some racial, or perhaps otherwise class-based, invidiously discriminatory animus." Id. at 102 (emphasis added). In a footnote, the Court added that "[w]e need not
} 
The pun on the word "labor" should not distract your attention from the fact that when a woman is forced against her will to carry a child to term, control over her body and its (re)productive capacities is seized from her and directed to a purpose not her own. As Ellen Willis observes, "[t]here is no way a pregnant woman can passively let the fetus live; she must create and nurture it with her own body, in a symbiosis that is often difficult, sometimes dangerous, always uniquely intimate." ${ }^{22}$ If there is a difficulty here, it seems to stem from the fact that work is paradigmatically thought of as what men do; what women traditionally do is not called work ("my wife doesn't work") except perhaps to the extent that it is performed with the same limbs and muscles that men possess. But what would we call any activity that demanded that a man, in order to produce a tangible result, endure constant exhaustion, loss of appetite, vomiting, sleeplessness, bloatedness, soreness, swelling, uncontrollable mood swings and, ultimately, hours of agony, often followed by deep depression? ${ }^{23}$ (Perhaps one ought also to include the burden of raising the child to maturity, as many women have done when abortions were unavailable to them.) ${ }^{24}$

decide, given the facts of this case, whether a conspiracy motivated by invidiously discriminatory intent other than racial bias would be actionable." Id. at 102 n.9. A sex discrimination claim under the statute was held actionable in Pendrell v. Chatham College, 370 F.Supp. 494 (W.D. Pa. 1974), in which a college professor alleged a conspiracy to terminate her employment because of, inter alia, her sex. While the court did not cite the Thirteenth Amendment as the constitutional authority for the statute's regulation of private conduct, "no other construction reasonably explains the court's decision," since the facts involved neither state action nor interstate travel. G. Buchanan, supra, at 171.

${ }^{22}$ Ellen Willis, Abortion: Is a Woman a Person?, in Powers of Desire: The Politics of Sexuality 471, 473 (Ann Snitow, Christine Stansell \& Sharon Thompson eds. 1983). Cf. Robert Goldstein, Mother-Love and Abortion (1988); Motion for Leave to File Brief Amici Curiae on Behalf of Organizations [California Committee to Legalize Abortion, et al.] and Named Women in Support of Appellants in Each Case, and Brief Amici Curiae, Roe v. Wade, 410 U.S. 113 (1973) (No. 70-18) at 23-24:

Even if the life support services which the woman's body brings into performance for sustenance of the fetus are largely automatic and non-voluntary, they are not non-services or non-actions. They are, according to medical experts, arduous, tiring, and obstructive of other work. The contractions of childbirth are literally "labor." They are the most strenuous work of which the human body is capable.

${ }^{23}$ This list is considerably abbreviated; the details could (and do, see Donald Regan, Rewriting Roe v. Wade, 77 Mich. L. Rev. 1569, 1579-82 (1979) fill pages.

${ }^{24}$ The coercion involved here is nicely described by Jed Rubenfeld:

[F]rom a moral or political view, it seems hardly acceptable to insist that a woman remains perfectly "free" to do what now would contradict her most elemental feelings of obligation to the child that she has been compelled to bear. The anti-abortionist cannot defend abortion laws on the basis of a woman's abstract freedom to give up the child when the real moral and practical constraints upon this decision have been created by the operation of the very laws in question.

The Right of Privacy, 102 Harv. L. Rev. 737, 790 n.204 (1989). These constraints would be exacerbated if abortion were illegal and if the laws against it were vigorously enforced (as they were not before Roe, see Hyman Rodman, Betty Sarvis, \& Joy Bonar, The Abortion Question 23-24 (1987)), since if all pregnancies now aborted were to come to term, the pool of potential adoptive parents would be exhausted in less than a year. Goldstein, supra, at 179-90. In such a world, women who had been forced to bear children would 
The germinal case construing the self-executing force of the Thirteenth Amendment is Bailey v. Alabama. ${ }^{25}$ The case came to the Supreme Court as an appeal from a criminal conviction for fraud. Bailey, a black laborer, had accepted a $\$ 15$ advance for signing a contract in which he agreed to work for a landholding corporation, the Riverside Company, for a year. Under the contract, he would earn $\$ 12$ a month, of which $\$ 1.25$ would be deducted each month to repay the $\$ 15$ advance. After about a month, Bailey left the job and refused to return to it. He was then prosecuted for defrauding the Riverside Company of $\$ 15$, convicted, and sentenced to 136 days of hard labor. While there was no evidence that he had intended to defraud the company, an Alabama statute provided that if one breached a service contract without refunding the money paid, fraud would be presumed. Under state rules of evidence, the accused was not permitted to testify about his intentions for the purpose of rebutting the presumption.

In reversing the conviction, Justice Hughes declared that "[w]ithout imputing any actual motive to oppress, we must consider the natural operation of the statute here in question, and it is apparent that it furnishes a convenient instrument for the coercion which the Constitution ... forbid[s]." ${ }^{26}$ The Thirteenth Amendment, he concluded, "does not permit slavery or involuntary servitude to be established or maintained through the operation of the criminal law by making it a crime to refuse to submit to the one or to render the service which would constitute the other." 27

Bailey's definition of involuntary servitude as "that control by which the personal service of one man is disposed of or coerced for another's benefit" 28 encompasses the burden imposed on women by laws against abortion, since the "natural operation" of a statute prohibiting abortion is to make it a crime for a woman to refuse to render service to a fetus. Even had the decision been differently worded, any decision in Bailey's favor would a fortiori protect the woman who seeks to abort, since the servitude to which

know that the alternative to raising them themselves would be to consign them to state institutions. Such a choice is already faced by mothers of minority or handicapped children, whose chances of adoption are much smaller than other children's. Id. at 182; U.S. Dept. of Health and Human Services, Children's Bureau, Administration for Children and Families, Children of Color in the Child Welfare System: Perspectives From the Child Welfare Community 8 (Dec. 2003), available at http://www.childwelfare.gov/pubs/otherpubs/children/children.pdf (visited Dec. 12, 2007)(Caucasian children are five times as likely to be adopted as children from other groups); Claire Baker, Disabled Children's Experience of Permanency in the Looked After System, 37 Brit. J. Soc. Work 1173 (2007).

${ }^{25} 219$ U.S. 219 (1911).

${ }^{26}$ Id. at $244-45$.

${ }^{27}$ Id. at 244. For the history of the Bailey case, see Benno Schmidt, The Peonage Cases: The Supreme Court and the "Wheel of Servitude", in Alexander Bickel \& Benno Schmidt, The Judiciary and Responsible Government, 1910-21, ch. 9 (1984). The case is likely to be unfamiliar to many readers. "The Peonage Cases are a largely forgotten footnote in constitutional law, and not even that in the law of contracts." Id. at 906. But this is not because the cases have lost any of their force. Rather, "the free-labor principle of the Peonage Cases has become thoroughly embedded in the bedrock of our constitutional and contract law," id. at 822 , so that no litigant has challenged it in many years. The case for abortion rights is strengthened, not weakened, by relying on a principle so fundamental that it is never questioned.

${ }^{28} 219$ U.S. at 241. 
Bailey was subjected was considerably less -- less taxing, less intrusive, and less total in its probable impact on the course of his whole life -- than that which forced pregnancy imposes on her.

Bailey also provides an answer to those who would dispute that the servitude is involuntary. Some opponents of abortion think that women should be considered to assume the risk of pregnancy when they consent to have sex. ${ }^{29}$ Even if women did deliberately assume such a risk, Bailey holds that the right to personal liberty guaranteed by the Thirteenth Amendment is inalienable.

The full intent of the constitutional provision could be defeated with obvious facility if, through the guise of contracts under which advances had been made, debtors could be held to compulsory service. It is the compulsion of the service that the statute [which enforces the amendment] inhibits, for when that occurs the condition of servitude is created, which would not be less involuntary because of the original agreement to work out the indebtedness. ${ }^{30}$

So even if the woman is stipulated to have consented to the risk of pregnancy, that does not permit the state to force her to remain pregnant. Rather, the Court has announced a principle of broad application: a contract for service (already a pretty strange characterization of her "consent") is consistent with the Thirteenth Amendment only if the contractor "can elect at any time to break it, and no law or force compels performance or a continuance of the service. ${ }^{31}$ Consent to the servitude is simply irrelevant.

\section{B. Equality}

The Thirteenth Amendment is also concerned about the subordination of groups. It is egalitarian as well as libertarian.

This concern about invidious social meanings is most evident in the Court's interpretation of the second section of the amendment, which provides that "Congress shall have power to enforce this article by appropriate legislation." This provision, the Court has held, "authorizes Congress not only to outlaw all forms of slavery and involuntary servitude but also to eradicate the last vestiges and incidents of a society half slave and half free ..." ${ }^{32}$ On the basis of this interpretation, the Court in Jones v. Alfred H. Mayer Co. sustained Congress' authority to outlaw private racial discrimination:

\footnotetext{
${ }^{29}$ This premise is dubious in several different ways. Lifelong sexual abstinence is not a reasonable option for most people, so their decision to decline that option does not imply consent to anything in particular. Many women lack power in their relationships with specific men. Pressures to have sex are often accompanied by pressures not to use contraception. See Forced Labor, 84 Nw. U. L. Rev. at 503-05.

${ }^{30}$ Id. at 242. Accord Clyatt v. United States, 197 U.S. 207 (1905); United States v. Reynolds, 235 U.S. 133 (1914); Taylor v. Georgia, 315 U.S. 25 (1942); Pollock v. Williams, 322 U.S. 4 (1944). Cf. Peonage Cases, 123 F. 671, 680 (M.D. Ala. 1903): "In the legal sense, whatever they may be in other aspects, such agreements are involuntary in their inception, since the law forbids consent, and therefore treats the agreement as having been made involuntarily -- against the will."

${ }^{31}$ Clyatt, 197 U.S. at 215-16.

32 Jones v. Alfred H. Mayer Co., 392 U.S. 409, 441 n.78 (1968).
} 
"Congress has the power under the Thirteenth Amendment to determine what are the badges and incidents of slavery, and the authority to translate that determination into effective legislation." ${ }^{33}$ Tribe thinks that this language, if read literally, grants to Congress a power to protect individual rights "which is as open-ended as its power to regulate interstate commerce. ${ }^{34}$ But unlike the Thirteenth Amendment, the commerce clause does not specify the evil which Congress is empowered to eliminate. ${ }^{35}$ If the Thirteenth Amendment authorizes Congress to eradicate the badges of slavery -- even those which, as in Jones, do not directly impose involuntary servitude -- this can only be because they, too, are among the evils that the amendment forbids.

Why should this be so? Why is it that "the freedom that Congress is empowered to secure under the Thirteenth Amendment includes the freedom to buy whatever a white man can buy, the right to live wherever a white man can live" ? ${ }^{36}$ The explanation seems to rest on complex nature of slavery as an institution:

Although "slavery" as an abstract form does not encompass mere discrimination in the sale of housing, the attention of the congressmen in 1864 and 1865 was not directed simply at an abstract model of slavery, but at a particular instance of that evil which existed in the South. Having flourished for over a century, southern slavery had built up strong interests among those who depended upon it and ingrained habits and attitudes in men of both races. It involved a complex of social and economic as well as legal relationships.... [The Thirteenth Amendment] appears to have been designed as a full response to the evil perceived. As modern perceptions of that evil grow, the response may take on increasingly broader scope. ${ }^{37}$

Even when slavery is deprived of legal sanction, its imprint on society is not yet wiped out. "[W]hen racial discrimination herds men into ghettos and makes their ability to buy property turn on the color of their skin, then it too is a relic of slavery." ${ }^{38}$

The concern about invidious meaning is equally present in the abortion case.

If indeed "[t]here can be no doubt that our Nation has had a long and unfortunate history of sex discrimination, ${ }^{39}$ this discrimination has consisted primarily of the systematic use of motherhood to define and limit women's social, economic, and political capacities. Anti-abortion laws would continue and ratify that practice even if they could

${ }^{33}$ Id. at 440.

${ }^{34}$ Laurence Tribe, American Constitutional Law, § 5-13 at 332 (2nd ed. 1988).

${ }^{35}$ See U.S. Const., Art. I, $\S 8$ ("The Congress shall have Power . . . To regulate Commerce . . . among the several States ....").

${ }^{36}$ Jones, 392 U.S. at 443.

${ }^{37}$ Note, The "New" Thirteenth Amendment: A Preliminary Analysis, 82 Harv. L. Rev. 1294, 1301-02 (1969).

38 Jones, 392 U.S. at 442-43.

${ }^{39}$ Frontiero v. Richardson, 411 U.S. 677, 684 (1973) (plurality opinion). 
somehow be restricted to that small subset of women seeking abortions who had contracted not to do so. The issue here is analogous to that of "badges of slavery." Because the subordination of women, like that of blacks, has traditionally been reinforced by a complex pattern of symbols and practices, the amendment's prohibition extends to those symbols and practices.

While the Court reversed Bailey's conviction "[w]ithout imputing any actual motive to oppress," 40 and invidious intent is thus not a part of the burden a Thirteenth Amendment challenge to a statute must carry, the pervasive presence of such intent strengthens such a challenge by reinforcing the suspicion that the statute would ratify systematic oppression. Sexism is as pervasive in the anti-abortion world view as racism was in the Southern peonage system. Just as southern whites typically assumed that blacks were lazy and irresponsible, anti-abortion arguments in contemporary America typically belittle women's capacity for moral agency, often supposing that women who abort simply don't and can't understand what they are doing. ${ }^{41}$ Just as the white landowners tended to think that agricultural labor, whether forced or willing, was a suitable role for blacks, so opponents of abortion tend to think that motherhood, whether forced or willing, is a suitable role for women. The view that dismisses a woman's desire to control the course of her life as arising from "convenience, whim, or caprice" ${ }^{42}$ is intimately linked to the traditional view that it is ridiculous and inappropriate for women to have or pursue such desires, and that the capacities of women, but not of men, are properly exercised "not for self-development, but for self-renunciation." ${ }^{43}$ Laws against abortion place the state's imprimatur on that view by imposing criminal punishment on those who deviate from it. In both cases, the insult is the same: to the extent that either

\footnotetext{
40219 U.S. at 244. Cf. Reynolds, 235 U.S. at 148-49 ("The validity of this system of state laws must be judged by its operation and effect upon rights secured by the Constitution . . ."); Taylor, 315 U.S. at 29 (focusing upon statute's "effect" and "necessary consequence"); Pollock, 322 U.S. at 25 ("We impute to the legislature no intention to oppress ....").

41 This lamentable tendency recently resurfaced in Justice Kennedy's majority opinion in Gonzales v. Carhart, 550 U.S. 124, 159 (2007), which held that abortion methods may be restricted because "some women come to regret their choice to abort the infant life they once created and sustained," possibly resulting in "[s]evere depression and loss of esteem." Justice Ginsburg responded by citing peer-reviewed studies showing that women who abort show no higher rate of psychiatric disorder than those who carry pregnancy to term. Id. at 183-84 (Ginsburg, J, dissenting). Kennedy admitted that he had "no reliable data to measure the phenomenon," but deemed it "unexceptionable" that this story is true of "some women." Id. at 159 (majority opinion). It is hard to imagine any limits to the proposition that constitutional liberties can be restricted if it sometimes happens that someone regrets exercising the liberty in a given way. Some people who criticize actions of the government later wish that they had kept their mouths shut. Some criminal suspects regret that they didn't confess everything when the police first interrogated them. Some of the slaves freed by the Thirteenth Amendment were old and infirm, and some of them probably regretted leaving the plantation.

${ }^{42}$ Doe v. Bolton, 410 U.S. 179, 221 (1973) (White, J., dissenting).

43 John Ruskin, Of Queen's Gardens, in Sesame and Lilies 86 (1910; Harold Bloom ed. 1983). Pro-life activists tend to believe that "men are best suited to the public world of work, and women are best suited to rear children, manage homes, and love and care for husbands." Kristin Luker, Abortion and the Politics of Motherhood 160 (1984). Cf. Faye Ginsburg, Contested Lives: The Abortion Debate in an American Community (1989).
} 
blacks or women are regarded as instruments for satisfying the needs of others rather than as autonomous agents, their dignity as free persons is violated. They are treated as things rather than as persons.

C. Bringing the strands together

The injury of compulsory pregnancy, in sum, has both individual and social aspects: forced pregnancy is a deprivation of individual liberty, but that deprivation is selectively imposed on women -- and women are a group that has traditionally been regarded as a servant caste, whose powers (unlike those of men) are properly directed to the benefit of others rather than themselves. Compulsory motherhood deprives women of both liberty and equality. And the Thirteenth Amendment argument responds to both of these injuries.

The Thirteenth Amendment is both libertarian and egalitarian, because the paradigmatic violation deprives its victims of both liberty and equality. It compels some private individuals to serve others, and it does so as part of a larger societal pattern of imposing such servitude on a particular caste of persons. If the libertarian and egalitarian rules of decision are both plausible readings of the amendment, it is because each stresses one undeniable aspect of the paradigmatic case. The courts may invalidate laws that impose servitude only on individuals, as it said it was doing in Bailey, and Congress may outlaw practices that stigmatize, but do no more than stigmatize, traditionally subjugated groups, as in Jones. But if either of these cases were paradigmatic of the amendment's prohibition, the other would be inexplicable. While the amendment has been construed broadly to encompass both these injuries, each involves only one of the two main aspects of what the amendment forbids. Compulsory pregnancy involves both. Since the amendment reaches far enough to forbid either of these injuries standing alone, a fortiori it forbids laws that inflict both of them at once.

The argument thus stated is thus open to a number of objections, counterexamples, qualifications, and questions of application. These are addressed in detail in the original article, and I will not repeat these points here.

\section{The argument revisited}

Plato's Socrates famously noted the limitation of any written argument, that "once a thing is put in writing, the composition, whatever it may be, drifts all over the place, getting into the hands not only of those who understand it, but equally of those who have no business with it; it doesn't know how to address the right people, and not address the wrong. And when it is ill-treated and unfairly abused it always needs its parent to come to its help, being unable to defend or help itself." 44 How well has my offspring managed in the world since I sent it on its way?

A. Its reception

\footnotetext{
${ }^{44}$ Phaedrus, 275d-e, tr. R. Hackforth.
} 
The article has been cited exactly once by a court, as evidence for the proposition that a defense of abortion based on the Thirteenth Amendment was not frivolous. ${ }^{45}$ That court pointedly noted that it was not expressing a view on the merits. ${ }^{46}$

In the law reviews, it has been cited 83 times. ${ }^{47}$ Most of these citations are friendly but brief, sometimes amounting to boilerplate, and do not engage the argument. It has elicited strong objections from three major legal scholars. Judge Richard Posner, describing Roe as "the Wandering Jew of constitutional law," noted that commentators have tried to "squeeze" the decision into many different constitutional provisions, including the Thirteenth Amendment. He was dismissive of all such efforts: "I await the day when someone shovels it into the Takings Clause, or the Republican Form of Government Clause (out of which an adventurous judge could excogitate the entire Bill of Rights and the Fourteenth Amendment), or the Privileges and Immunities Clause. It is ... a desperate search for an adequate textual home, and it has failed." 48 Steven D. Smith described the article as an "ingenious discovery of legal and moral content in a constitutional text beyond what its authors could have contemplated," but then rejected it as a "hatrabbit operation." 49 Neither deems it necessary to explain why the argument is unpersuasive. John McGinnis has offered the fullest and most thoughtful response that has yet been published, albeit packed into a few sentences:

It is not only that no reasonable person at the time would have thought that unwanted pregnancy was a form of involuntary servitude. Even now such an argument would be treated at best as a pun on labor rather than seriously advanced in a court of law. Servitude, particularly as the context of an amendment that was designed to end slavery relates to economic obligation, not familial obligations. Unwanted pregnancy is no more involuntary servitude than are the other unwanted obligations that may force parents to work for their children, like child support. In fact it is less so because these other obligations may trigger imprisonment if they are not kept. But even assuming the alternative universe in which a Court would apply this clause to the issue of abortion, Professor Koppelman still must make broad political assertions about the subordination of women to counter the obvious point that at least some women voluntarily become pregnant and then, changing their mind, wish to terminate a pregnancy. ${ }^{50}$

\footnotetext{
45 Jane L. v. Bangerter, 61 F.3d 1505, 1515 n.9 (10 ${ }^{\text {th }}$ Cir. 1995)

${ }^{46} \mathrm{Id}$. at 1515. It was reversing lower court decisions that had cast scorn on the argument; though those courts did reach the merits, they did so summarily, with little argument. Jane L. v. Bangerter, 828 F.Supp. 1544, 1554-55 (D. Utah 1993); Jane L. v. Bangerter, 797 F.Supp. 1537, 1548-49 (D. Utah 1992).

47 A Westlaw search of Koppelman /2 "Forced Labor" in the JLR (journals and law reviews) database on April 15, 2009 yielded a list of 88 citations, which I corrected by deleting five articles written by myself.

${ }^{48}$ Richard Posner, Legal Reasoning From the Top Down and From the Bottom Up: The Question of Unenumerated Constitutional Rights, 59 U. Chi. L. Rev. 433, 442 n. 29 (1992).

${ }^{49}$ Steven D. Smith, Idolatry in Constitutional Interpretation, 79 Va. L. Rev. 583, n 130 (1993).

50 John O. McGinnis, Decentralizing Constitutional Provisions Versus Judicial Oligarchy: A Reply to Professor Koppelman, 20 Const. Commentary 39, 56 (2003).
} 
McGinnis challenges the thesis on three different grounds: original intent, an analogy with family obligations, and an argument about the force of obligations voluntarily undertaken. But these arguments were already raised and answered in the original article. Specific original intent proves too much, since the framers of the Fourteenth Amendment supported segregated schools and miscegenation prohibitions. ${ }^{51}$ Child support obligations do not raise Thirteenth Amendment concerns because they do not require specific bodily labor from anyone; one can raise the money any way one likes, just like any other contractual obligation. The Bailey decision did not relieve Bailey of his debt. ${ }^{52}$ And obligations voluntarily undertaken were precisely what was at issue in Bailey. ${ }^{53}$ Perhaps you, reading this right now, don't buy the argument. If so, I wish you would write to me and explain why. If there is a defect in the argument, no one has ever stated it in print. Hit me. I want you to.

B. Its philosophical limitations

The largest problem with the argument, as I presented it, is that it understates the messiness of the abortion issue, and offers too clean a resolution. The article has some of the typical vices of a young person's work: its view of the world is too simple, and it doesn't acknowledge frankly enough the complexity of the issues it takes on.

The boundaries of moral concern are mysterious. No conclusive philosophical account has been offered of where those boundaries are appropriately located. ${ }^{54}$ It is a matter of common agreement that late-term abortions are far more morally troubling than early ones, and that infanticide is absolutely prohibited. It is far less clear why this is the case. It is not just that there is no clean, knock down way to resolve the issue of the fetus's personhood. There is also no clarity about how, as a practical matter, we as a society ought to address these borderlines of status. If the fetus's personhood is conceded for the sake of argument, there is no way to prove that it does not outweigh the Thirteenth Amendment claim. The article's claims were too strong in this regard. ${ }^{55}$

${ }^{51}$ Forced Labor, 84 Nw. U. L. Rev. at $488-89$ n.40.

${ }^{52}$ Id. at 523.

${ }^{53}$ Id. at 490-511; for a summary of that argument, see Part IA supra. In fairness to Prof. McGinnis, he was only responding to the Thirteenth Amendment argument in passing, while conducting a dispute that was primarily concerned with very different issues. See Andrew Koppelman, How "Decentralization" Rationalizes Oligarchy: John McGinnis and the Rehnquist Court, 20 Constitutional Commentary 11 (2003).

${ }^{54}$ See Kent Greenawalt, Religious Convictions and Political Choice 98-172 (1988); Jeffrey McMahan, Cognitive Disability, Misfortune, and Justice, 25 Phil. \& Pub. Aff. 3 (1996).

55 This obvious issue is only glancingly addressed in the original article. In fact, it's buried inside footnote 155 on pp. 516-17. This is reminiscent of Robert Nozick's description of a certain kind of bad philosophy as

pushing and shoving things to fit into some fixed perimeter of specified shape. All those things are lying out there, and they must be fit in. You push and shove the material into the rigid area getting it into the boundary on one side, and it bulges out on another. You run around and press the protruding bulge, producing yet another in another place. So you push and shove and clip off 
The argument from precedent was similarly too neat. I argued that, given that no one could prove the personhood of the fetus, it was impossible to say that Roe is clearly wrong, so it should remain the law. That's not clear either, because the moral status of a fetus is so uncertain.

What can be shown here is that prohibitions of abortion implicate a constitutional right of great weight, one for which many lives have been sacrificed in the past. This diminishes but does not eliminate the problem of judge-made law. The precedents on which I rely are firmly rooted in the text, and no one seriously questions their validity.

If the claim is thus modified, then it becomes possible to answer the most difficult objection from precedent, one that I addressed too cavalierly in the original article. Parents have a legal duty to render assistance to their children, and can be criminally prosecuted if they do not. This duty has never been thought to raise a Thirteenth Amendment issue. But the prohibition of abortion is just an instance of that very duty: the pregnant woman is obligated by law to render needed assistance to her child.

In the article, I tried to answer this objection by arguing that even the obligations of parents would raise a Thirteenth Amendment problem if the parents were not permitted to give their children up for adoption, as in fact they are in every state. ${ }^{56} \mathrm{I}$ am no longer so certain. Just as we have no conclusive account of the boundaries of moral concern, so we have no conclusive account of the nature and extent of parental obligations to children. I am sure, however, that the opposite claim, that parental obligations never raise a Thirteenth Amendment issue, is false. The existence of valid parental duties complicates but does not defeat the Thirteenth Amendment argument for abortion rights.

In the first place, the Thirteenth Amendment case against abortion restrictions rests on more than an analogy. Take another look at the institution of antebellum slavery which the amendment was specifically intended to outlaw. Thus far, in considering what "servitude" means, we have only compared forced childbearing with long days of hard work in the cotton fields. But mandatory motherhood and loss of control over one's reproductive capacities were partially constitutive of slavery for most black women of childbearing age, whose principal utility to the slaveholding class lay in their ability to reproduce the labor force. ${ }^{57}$ Unlike (unmarried) white women, they had no right even in theory to avoid pregnancy through abstinence; they were often raped with impunity, by their masters and others. ${ }^{58}$ Emancipation was intended to free them from such indignities. The effect of abortion prohibitions (whose impact, by the way, has been felt

corners from the things so they'll fit and you press in until finally almost everything sits unstably more or less in there; what doesn't gets heaved far away so that it won't be noticed. Robert Nozick, Anarchy, State, and Utopia xiii (1974).

${ }^{56}$ See Forced Labor, 84 Nw. U. L. Rev. at 523.

${ }^{57}$ See Herbert Gutman, The Black Family in Slavery and Freedom, 1750-1925 75-80 (1976).

${ }^{58}$ See John D'Emilio \& Estelle Freedman, Intimate Matters: A History of Sexuality in America 100-04 (1988); E. Genovese, Roll, Jordan, Roll: The World the Slaves Made 413-31 (1976). 
mainly by poor women who are disproportionately black) ${ }^{59}$ is thus to consign women to a kind of servitude from which the amendment was supposed to free them.

The most pertinent characteristic of slave mothers was that they were unable to refuse intercourse. But if they had a valid Thirteenth Amendment claim for this reason, then so does any woman who is impregnated as a result of a rape. So the Thirteenth Amendment is relevant to at least a subset of abortion cases. How much further does it extend? That would seem to depend on how voluntary pregnancy is in the full range of other cases. We are back to all the familiar questions of whether a woman who became pregnant after making reasonable efforts to contracept, or a woman too young to be legally competent, has become pregnant voluntarily. The Thirteenth Amendment is at least relevant to these questions. That rebuts the claim that it has no application at all to parental obligations.

\section{Its rhetorical limitations}

Why didn't the piece have more impact? The Thirteenth Amendment is an unfamiliar idiom. People aren't used to thinking in those terms. Katherine A. Taylor thus observed:

While feminist theorists have increasingly taken the intriguing approach of challenging abortion restrictions and other coercions of pregnant women as violating the Thirteenth Amendment, equal protection doctrine arguably affords the most appropriate means of challenging statutes that perpetuate women's subordinative status, since "it is the only body of constitutional jurisprudence explicitly skeptical about the rationality of gender-based judgments and specifically concerned with the justice of gender-based impositions." Thus, it is likely that courts will be more amenable to a (revised) equal protection challenge to the pregnancy restrictions than to a Thirteenth Amendment challenge. ${ }^{60}$

The bounds of legitimate legal argument are not set by rules, but by custom and usage. At the time the article was written, not much had been done with the Thirteenth Amendment by anyone in the legal academy. It had been a potent source of law as recently as the 1970s, but it had since gone out of fashion, and arguments that tried to invoke it as a major premise tended to be ruled out of order without a hearing, simply because that kind of thing is not done. ${ }^{61}$ This book indicates that that is changing. There

\footnotetext{
59 See Brief of Amici National Council of Negro Women, et al., Webster v. Reproductive Health Services, 492 U.S. 490 (1989) (No. 88-605), and sources cited therein. Black women are also under unusually great pressure to keep and raise their babies, since black babies are relatively unlikely to be adopted. See supra note 23 .

${ }^{60}$ Katherine A. Taylor, Compelling Pregnancy at Death's Door, 85 Colum. J. Gender \& L. 85, 146 n. 198 (1997), quoting Reva Siegel, Reasoning From the Body: A Historical Perspective on Abortion Regulation and Questions of Equal Protection, 44 Stan. L. Rev. 261, 352 (1992).

61 Thus Larry Kramer observed that even those who offer Thirteenth Amendment arguments "tend to present their ideas somewhat sheepishly, as if slightly embarrassed to offer something so radically at odds with traditional constitutional understandings." Popular Constitutionalism, Circa 2004, 92 Calif. L. Rev. 959, 979 (2004). I don't think he was talking about me, since my argument was fairly immune to embarrassment, but the tendency he describes cannot be gainsaid. His description of the reaction is deadly accurate: "Most other commentators, in the meantime, not to mention lawyers, judges, and politicians,
} 
is an increasing appreciation that the Thirteenth Amendment has potent contemporary applications.

The abortion issue is not going to be resolved by technical legal argumentation. But lawyers' bad consciences about the poor craftsmanship of Roe has certainly played a role in the debate. The Thirteenth Amendment argument can set that at rest. That counts for something.

As Thirteenth Amendment arguments become more familiar, the Thirteenth Amendment case for abortion will become less surprising. At that point, legal argument may once again come into its own, and scholars and judges may once more feel the obligation to answer legal arguments with arguments of their own. The Thirteenth Amendment may again become part of our constitutional conscience. After twenty years, I hope the conversation can begin.

dismiss these musings as academic flights of fancy--the kinds of things only law professors, unconnected to reality, would think worth pursuing." Id. This reaction illustrates his more general point that "problems come to us framed by a multitude of implicit understandings and assumptions that limit and shape how we reason by defining our sense of how things work." Id. at 980.

Thanks to Ron Allen for comments, and to Marcia Lehr for research assistance. 